\title{
Correction to: Two-scale coupling for preconditioned Hamiltonian Monte Carlo in infinite dimensions
}

\author{
Nawaf Bou-Rabee ${ }^{1}$ (D) Andreas Eberle ${ }^{2}$
}

Published online: 27 August 2021

(c) The Author(s) 2021

\section{Correction to: Stoch PDE: Anal Comp (2021) 9:207-242 https://doi.org/10.1007/s40072-020-00175-6}

The article "Two-scale coupling for preconditioned Hamiltonian Monte Carlo in infinite dimensions", written by Nawaf Bou-Rabee and Andreas Eberle, was originally published electronically on the publisher's internet portal on 15 June 2020 without open access. With the author(s)' decision to opt for Open Choice the copyright of the article changed on 4 June 2021 to (OThe Author(s) 2021 and the article is forthwith distributed under a Creative Commons Attribution 4.0 International License, which permits use, sharing, adaptation, distribution and reproduction in any medium or format, as long as you give appropriate credit to the original author(s) and the source, provide a link to the Creative Commons licence, and indicate if changes were made. The images or other third party material in this article are included in the article's Creative Commons licence, unless indicated otherwise in a credit line to the material. If material is not included in the article's Creative Commons licence and your intended use is not permitted by statutory regulation or exceeds the permitted use, you will need to obtain permission directly from the copyright holder. To view a copy of this licence, visit http://creativecommons.org/licenses/by/4.0.

Open Access This article is licensed under a Creative Commons Attribution 4.0 International License, which permits use, sharing, adaptation, distribution and reproduction in any medium or format, as long as you give appropriate credit to the original author(s) and the source, provide a link to the Creative Commons licence,

The original article can be found online at https://doi.org/10.1007/s40072-020-00175-6.

\awaf Bou-Rabee

nawaf.bourabee@rutgers.edu

Andreas Eberle

eberle@uni-bonn.de

1 Department of Mathematical Sciences, Rutgers University Camden, 311 N 5th Street, Camden, NJ 0810, USA

2 Institut für Angewandte Mathematik, Universität Bonn, Endenicher Allee 60, 53115 Bonn, Germany 
and indicate if changes were made. The images or other third party material in this article are included in the article's Creative Commons licence, unless indicated otherwise in a credit line to the material. If material is not included in the article's Creative Commons licence and your intended use is not permitted by statutory regulation or exceeds the permitted use, you will need to obtain permission directly from the copyright holder. To view a copy of this licence, visit http://creativecommons.org/licenses/by/4.0/.

Publisher's Note Springer Nature remains neutral with regard to jurisdictional claims in published maps and institutional affiliations. 